\title{
Fiscal 'stimulus': a loanable funds critique
}

ANTHONY J. MAKIN

\section{Abstract}

This paper proposes an extended loanable-funds framework for examining the effects of fiscal stimulus on the budget balance, international borrowing, real interest rates, private saving, private investment and national income. It challenges the prevailing view that fiscal policy can be used effectively as an income 'stimulus' instrument, and proposes that discretionary fiscal measures that increase the budget deficit entail macroeconomic costs for significant external borrower economies, such as Australia, New Zealand and the United States.

\section{Introduction}

Within the G20 set of economies the size of the fiscal expansion in response to the current economic downturn has varied substantially from member to member. According to IMF estimates (2009: 38) the scale of Australia's fiscal expansion when measured relative to GDP ranks among the highest within the G20 group, and close to that of the United States, the epicentre of the crisis itself.

For the first time in almost two decades, Australia's policymakers have again automatically assumed that fiscal expansion is an effective means of countering a slowdown in economic activity, despite the lack of compelling empirical evidence from the international academic literature. As the IMF (2008: 164) concludes in a survey of the effectiveness of fiscal stimulus, the evidence is ambiguous, with estimates of the effects of fiscal policy on national output differing 'not merely in degree but in sign'. ${ }^{2}$

Keynesian fiscal activism has been challenged previously on numerous theoretical and practical grounds. ${ }^{3}$ The Mundell (1963)-Fleming (1962) model

1 Griffith Business School, Griffith University; t.makin@griffith.edu.au.

2 For instance, Blanchard and Perotti (2002) provide supportive empirical evidence, contrary to Auerbach (2002).

3 See Barro (2009), Fama (2009) and Taylor (2009). 
of an open economy, for example, concludes that, even during recessions, fiscal policy is ineffective in raising aggregate demand with a floating exchange rate and highly mobile international capital because it 'crowds out' net exports. However, the Mundell-Fleming model fails to treat international capital flows as discrete phenomena related to discrepant domestic saving and investment behaviour.

The following analysis aims to improve conceptual understanding of the nexus between budget deficits and the real economy by outlining a different approach to crowding out that extends the loanable-funds framework, as applied to advanced borrower economies, such as Australia, New Zealand and the United States. Critical to this extension is the assumption that borrower economies face a rising supply price of foreign capital, as would be expected under current international financial conditions, characterised by a general shortage of funds. An alternative diagrammatic framework is first developed, and then used to analyse the effects of budget deficit-raising stimulus in the form of increased government spending.

To preview our results, contrary to standard Keynesian analysis currently underpinning federal fiscal policy in Australia, which essentially assumes that fiscal stimulus confers macroeconomic benefits by boosting aggregate demand, the present analysis highlights the macroeconomic costs that stem from resultant budget deficits and borrowing.

\section{Loanable Funds Analysis of Fiscal Stimulus with Interest Parity}

Since domestic saving, domestic investment and foreign lending, are functionally related to the real interest rate, it follows from national accounting relationships identities that

$$
I(\vec{r})+B D=S_{p}(\stackrel{+}{r})+L^{*}(\stackrel{+}{r})
$$

where $I$ is investment, $B D$ is the budget deficit, $S_{p}$ is private domestic saving, and $L^{*}$ is foreign lending. 
The signs above the real interest rate indicate the effect of a rise in rates on the variable before the parentheses. Written this way, the expression also shows that the total domestic demand for funds must equal the total supply of funds forthcoming from home and abroad, with the real interest rate playing the equilibrating role.

If international capital mobility is assumed to be perfect, as is usual in most open-economy models including the Mundell-Fleming model, the domestic real interest rate, $r$, is simply determined by the foreign real interest rate, $r^{*}$. This assumes real interest parity always prevails, irrespective of the economy's external indebtedness (to be relaxed subsequently).

Relationship (1) underpins an extended international loanable-funds framework for analysing the effects of various forms of fiscal stimulus on net foreign borrowing and national income. Figure 1 depicts a simple benchmark version where, in initial equilibrium, the budget is balanced, private saving and investment (and hence the current account) are balanced, and the stock of net foreign debt is nil.

The vertical private-saving schedule implies that the responsiveness of private saving to a rise in the domestic interest rate, for given national income and household consumption, is negligible, as presumed in conventional theories of consumption, such as the Keynesian, life-cycle, and permanent income approaches. $^{4}$ Alternatively, this schedule could be drawn slightly upwardsloping, reflecting some sensitivity of private saving to interest rate changes in line with limited empirical evidence on this relationship, ${ }^{5}$ but this would have no significant bearing on the results.

On the demand side of the funds market, whenever domestic firms invest by purchasing new capital, the cost of which is approximated by the real domestic interest rate, $r$, the demand for funds decreases as the real interest rate rises, in accordance with neoclassical and Keynesian investment theory. ${ }^{6}$

4 See Keynes (1936), Modigliani (1986), and Friedman (1957), respectively.

5 Masson, Bayoumi and Hossein (1998) provide empirical evidence of a positive relationship between real interest rates and private saving in advanced economies.

6 See Romer (2005). 
Agenda, Volume 16, Number 4, 2009

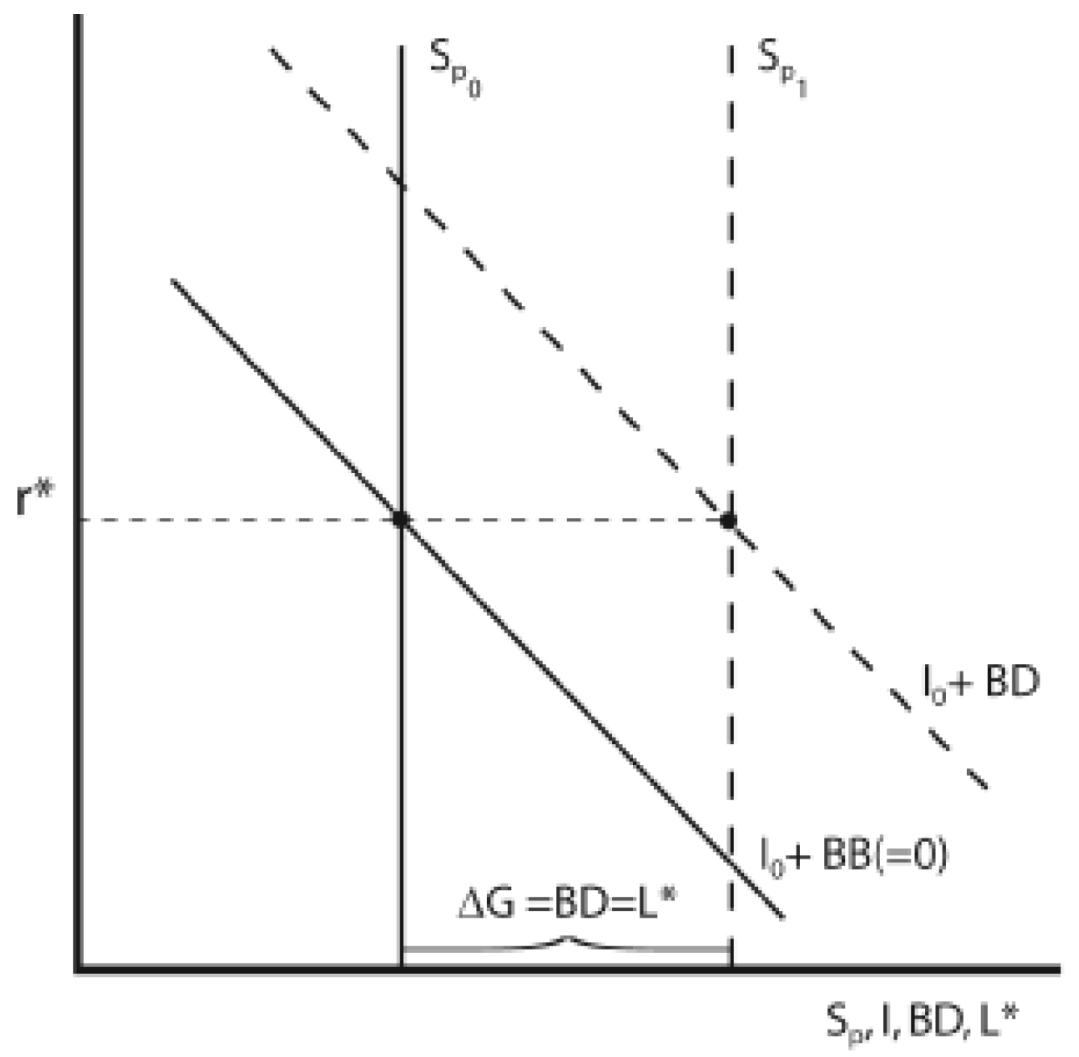

Figure 1: Budget Deficits and the Flow of Funds

With regard to Figure 1, let us first assume that private investment increases, which shifts the demand-for-funds schedule rightward. This extra investment adds to the domestic capital stock and, consistent with neo-classical foreign investment theory, ${ }^{7}$ enables extra production, or GDP, equivalent in Figure 1 to the sum of the upper triangular area and the rectangular area beneath it.

However, only the triangular area represents the net national income gain for the economy because the foreign borrowing to fund this investment has to be serviced at the prevailing world interest rate. Hence, the rectangular area, income paid abroad, has to be subtracted from GDP. This result implies extra foreign-funded private investment should be welcomed on the grounds that it enhances macroeconomic welfare, despite the accompanying rise in foreign

7 See, for instance, Makin (2004). 
indebtedness. Such analysis has underpinned the argument that foreign debt incurred by the private sector in this way should not be a macroeconomic policy concern as it bolsters economic growth in net terms.

With fiscal stimulus, a move from budget balance to deficit increases the overall demand for funds, other things being the same, and also shifts the total demandfor-funds schedule rightwards. If the supply of funds from abroad is perfectly elastic (the perfect capital mobility assumption), this increases net foreign borrowing to the same extent, suggesting that budget and external deficits are identically twinned.

Yet fiscal measures which either increase public consumption directly, or represent spending on 'social infrastructure' projects that pay no rate of return (such as 'free' ceiling insulation for private dwellings), do not increase national output. Instead, budget deficits arising from such measures unambiguously reduce national income by the rectangular area, the servicing cost of additional net foreign borrowing required to fund them.

\section{Fiscal Stimulus with a Rising Supply Price of Foreign Funds}

So far, real interest parity has been assumed. Yet, under current global financial conditions, characterised by risk aversion on the part of international lenders, it is unrealistic to assume the economy enjoys unlimited access to world capital markets. We should more sensibly assume that the supply price of foreign funds is rising, due, for instance, to a risk premium, $p$, increasing in the level of foreign debt, $F$. Moreover, the willingness of foreigners to lend to the economy shifts due to other forms of risk, $\mathcal{E}$, particularly the risk of future currency depreciation, such that

$r=r^{*}+\rho(\stackrel{+}{F} ; \dot{\varepsilon})$

Accordingly, the economy is more likely to face an upward-sloping supply of foreign funds ${ }^{8}$, as shown by the $L^{*}$ schedule in Figure 2.

8 That Australia's long-term bond rates have been consistently higher than comparable rates in the US, the UK, and Japan - major sources of capital inflow — provides direct evidence of an interest risk premium. 
Agenda, Volume 16, Number 4, 2009

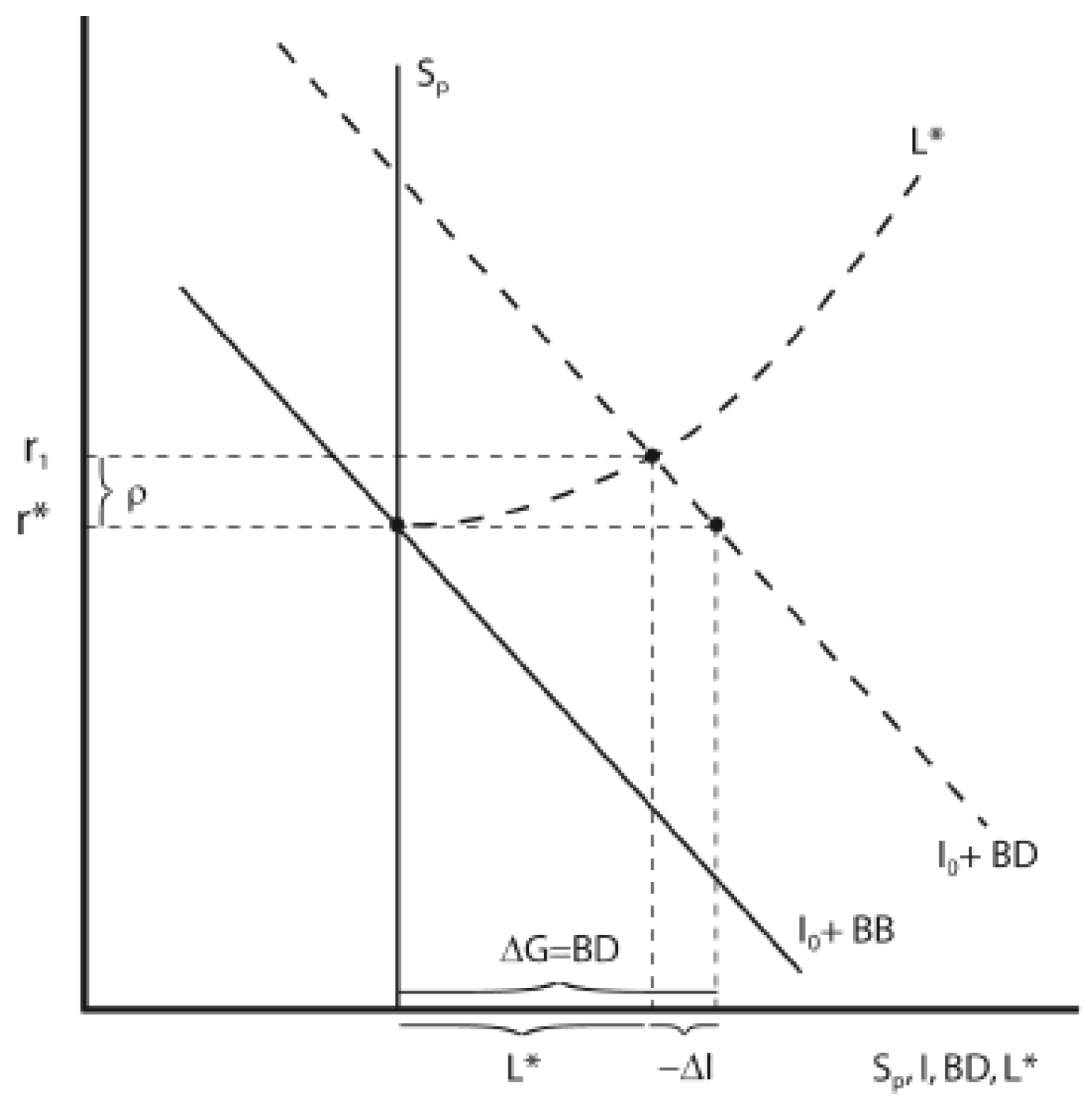

Figure 2: Budget Deficits, Borrowing and Crowding Out

This more realistic extension of the standard loanable-funds framework may now be used to reconsider the effects of fiscal stimulus on real interest rates, private investment and national income. To do this, it focuses on fiscal expansion in the form of higher unproductive public spending.

\section{National Income Losses from Increased Government Spending}

Higher government consumption immediately widens the budget deficit which must be financed. Hence, the total demand-for-funds schedule shifts right, creating excess demand at the prevailing real interest rate. This raises the economy's ex ante external financing requirement. At the same time, the debtrelated risk premium rises, as foreign borrowing increases, other things being the same. 
In turn, this higher interest rate feeds back to crowd out domestic private investment. Hence, unproductive public spending-induced deficits are matched ex post by a combination of higher international borrowing and forgone private investment, as shown on the horizontal axis of Figure 2. This implies that budget and external deficits move in the same direction, but are no longer identically twinned.

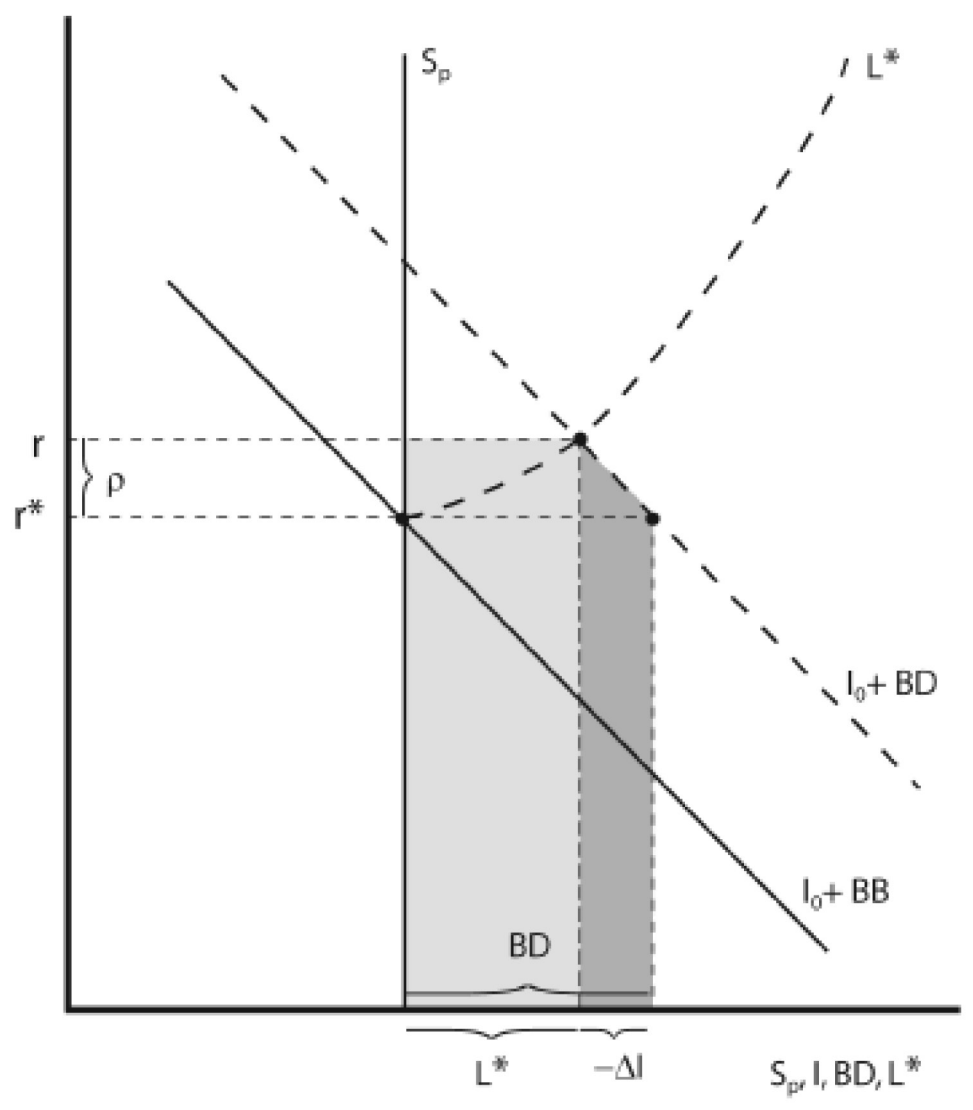

Figure 3: Explicit and Implicit Costs of Fiscal 'Stimulus'

Fiscal stimulus, either in the form of unproductive public spending or tax cuts and income transfers that lead to higher private consumption, confers both explicit and implicit national income losses. Income paid abroad is the explicit national income loss, and arises because additional borrowing has to be serviced at a higher equilibrium real interest rate following the fiscal expansion. In Figure 3, this explicit income loss directly resulting from the budget deficit (net of any private saving offset) is shown by the lighter shaded area. For an 
external borrower country, any fiscal expansion deemed effective in stimulating consumption entails this hitherto acknowledged cost. But there is also an indirect national income loss. This is the national output forgone due to the loss of private investment crowded out by higher interest rates, and which is indicated by the darker shaded area.

Total national income lost due to consumption-enhancing fiscal stimulus is the sum of the two shaded areas.

\section{Conclusion}

This note has proposed an extended loanable-funds framework for examining the effects of fiscal stimulus on the budget balance, international borrowing, real interest rates, private saving, private investment and national income. It challenges the prevailing view that fiscal policy can be effectively used as an income 'stimulus' instrument, and proposes that discretionary fiscal measures that increase the budget deficit entail macroeconomic costs for significant external borrower economies, such as Australia, New Zealand and the United States.

Fiscal 'stimulus' in the form of unproductive government spending retards, not improves, national income growth for an economy reliant on international borrowing by raising the cost of capital, and crowding out private investment. The corollary for public policy is that cutting wasteful public expenditure will lower the foreign borrowing requirement and real long-term interest rates, thereby stimulating private investment and national income.

This is not to say that public spending on infrastructure can not positively influence national income in the same way as foreign-financed private investment does. However, additional public investment should be verified via rigorous project-by-project cost-benefit analysis and be as productive for the economy as the private investment it crowds out.

To further underline the need for productive investment, we need to realise that this critique of fiscal policy presumes the external borrowing and the matching current-account imbalance arising from 'stimulus' measures are sustainable in the sense that foreign lenders remain willing to lend the funds needed to satisfy the additional fiscally-induced demand. But foreign lenders' perception of risk will eventually change at some point if external finance is persistently used to fund unproductive spending, defined as that spending that fails to create the additional output needed to service loans into the future. 
At such time, foreign lenders could expect the exchange rate to depreciate. The foreign-lending schedule in Figures 2 and 3 would then abruptly shift upward, pushing long-term real interest rates even higher. This would further raise the servicing cost on existing and pre-existing foreign debt and crowd out more private investment, at greater cost to national income.

\section{References}

Auerbach, A. 2002, 'Is There a Role for Discretionary Fiscal Policy?' NBER Working Paper 9306, National Bureau of Economic Research, October.

Barro, R. 1974, 'Are Government Bonds Net Wealth?' Journal of Political Economy 81: 1095-17.

Blanchard, O. and Perotti R. 2002, 'An Empirical Characterization of the Dynamic Effects of Changes in Government Deficit and Taxes on Output', Quarterly Journal of Economics 117:4, 1329-68.

Fama, E. 2009, 'Bailouts and Stimulus Plans'; available at www.dimensional. com/famafrench/2009/01/bailouts-and-stimulus-plans.html.

Fleming, J. 1962, 'Domestic Financial Policy Under Fixed and Floating Exchange Rates', IMF Staff Papers 9(3): 369-79.

Friedman, M. 1957, A Theory of the Consumption Function, Princeton University Press, New Jersey.

International Monetary Fund 2009, Global Economic Policies and Prospects, Group of Twenty Meeting, March, IMF, Washington DC.

International Monetary Fund 2008, World Economic Outlook, September, IMF, Washington DC.

Keynes, J. M. 1936, The General Theory of Employment, Interest and Money, Macmillan, Basingstoke, UK.

Makin, A. 2004, Global Finance and the Macroeconomy, Palgrave Macmillan, Basingstoke.

Mankiw, G. 2007, Macroeconomics, 6th ed, Worth, New York.

Masson, Paul R., Bayoumi, Tamim A. and Samiei, Hossein 1998, 'International Evidence on the Determinants of Private Saving', World Bank Economic Review 12: 483-501. 
Modigliani, F. 1986, 'Life Cycle, Individual Thrift, and the Wealth of Nations', American Economic Review 76: 297-313.

Mundell, R. 1963, 'Capital Mobility and Stabilization Policy Under Fixed and Flexible Exchange Rates', Canadian Journal of Economics and Political Science 29(4):475-85.

Romer, D. 2005, Advanced Macroeconomics, McGraw Hill, New York.

Taylor, J. 2009, 'The Lack of an Empirical Rationale for a Revival of Discretionary Fiscal Policy'; paper presented at the Annual Meeting of the American Economic Association, January. Available at www.stanford.edu/ johntayl/ AEA_Paper_on_Fiscal_Policy_2009_JBT.pdf 